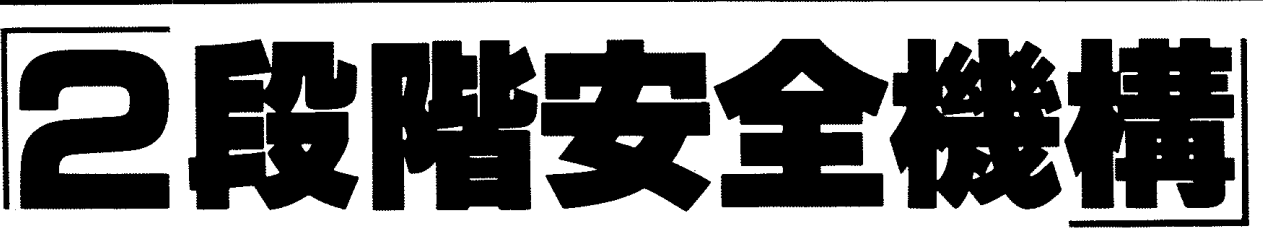

\title{
ANESTHESIA APPARATUS
}

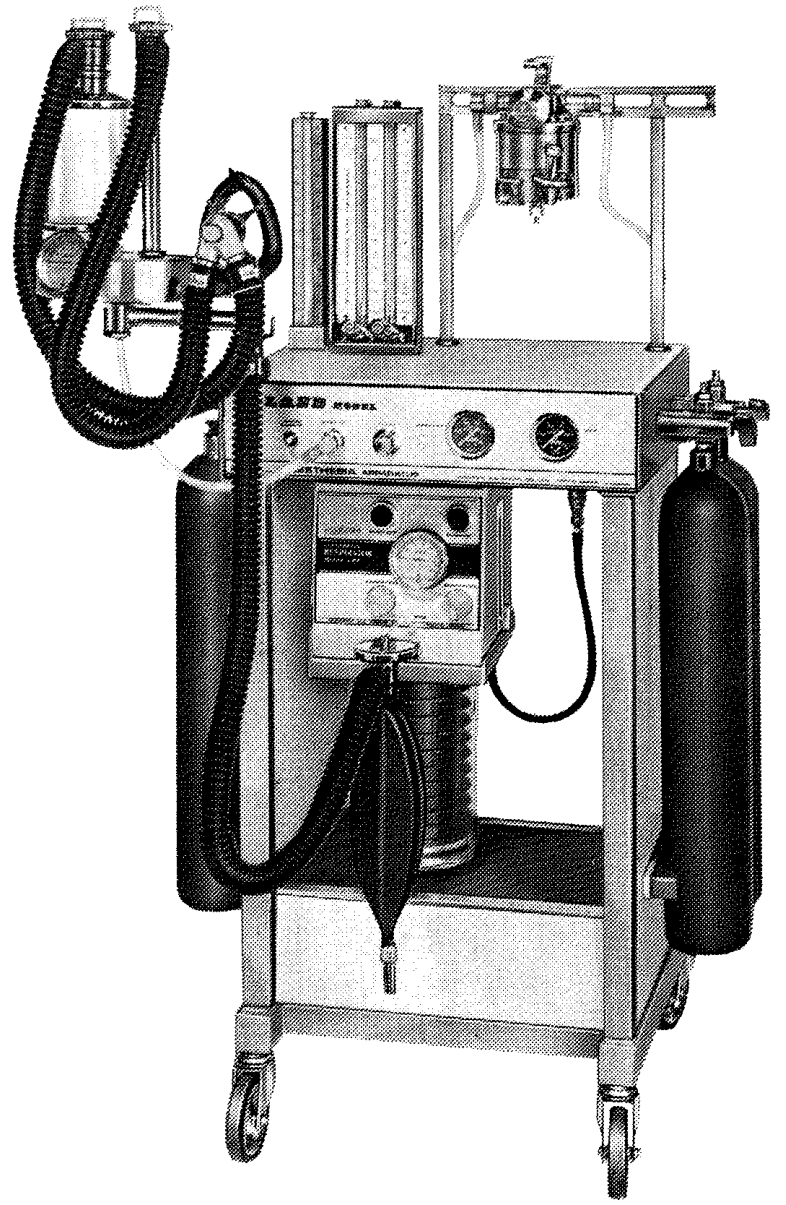

五十嵐麻醉器安全機構

安全機構

\section{・流量計安全装置}

特殊連動ギヤを使用し、笑気がス筆独では流れ ない装置です。酸素コントロールハルつを操作し、 次に笑気コントロールル゙オを操作しますとミツ ワスガスガ流れます。

弊社の麻酔器全機種に取付け可能

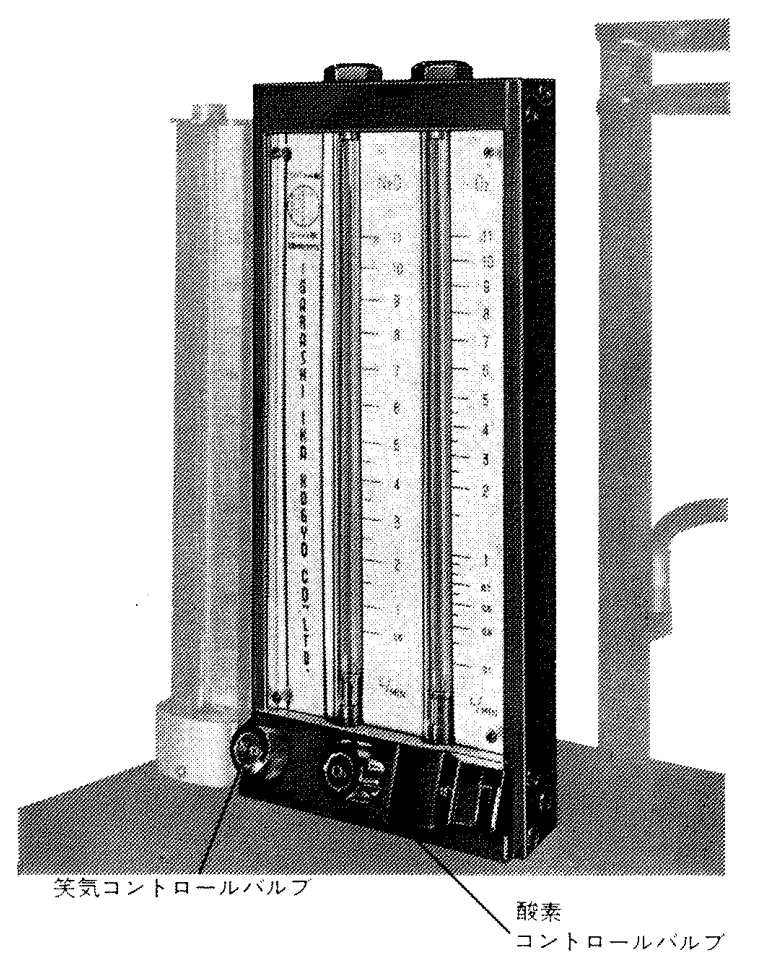

・カットオフバルフ

二重安全機構として、かットオフバルをを採用 しています。麻酔器に供給される酸素が何らかの 原因でストップしたり、圧が異常低下しますと、 鿼動的に笑気ガスの流れもストツプする装置です。 ポータフルAーAヌイフを除く全機種に取付け 可能です。

「2段階安全機構」付五十嵐の麻酔器をぜひご使 用下さい。くわしくは担当買までご相談下さい。

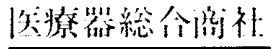

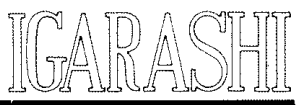

麻酔器及部品各種 - 病院設備一般 製造・発売元

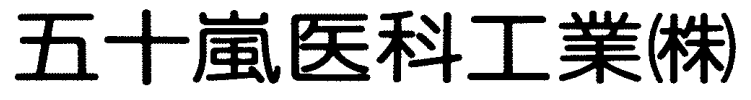

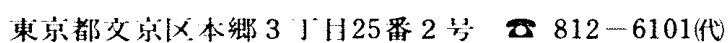
都内営業部 $\boldsymbol{\Xi} 815-1471-3$

テレックス番家 $272-2608$ 加入者略影イガラシイ力
昭昭

和和

五 $\bar{T}$

$+t$

六

年月

十分

- 旦

月

種

郵

日 便

発 物

行可 